Canadian



Arctic Science An OPEN ACCESS journal

\title{
Reactions of ground-nesting marine birds to human disturbance in the Canadian Arctic
}

\begin{tabular}{|r|l|}
\hline Journal: & Arctic Science \\
\hline Manuscript ID & AS-2015-0029.R1 \\
\hline Manuscript Type: & Article \\
\hline Date Submitted by the Author: & 28-Mar-2016 \\
\hline Complete List of Authors: & Mallory, Mark; Acadia University, Biology \\
\hline Keyword: & marine bird, nest, disturbance, Arctic, flush \\
\hline
\end{tabular}

\section{SCHOLARONE ${ }^{m}$ \\ Manuscripts}


Reactions of ground-nesting marine birds to human disturbance in the Canadian Arctic

Mark L. Mallory

Department of Biology, Acadia University, Wolfville, NS, B4P 2R6, CANADA (902) 585 1798; mark.mallory@acadiau.ca 
Abstract: I studied the reactions of five, ground-nesting marine bird species (Arctic tern Sterna paradisaea; Sabine's gull Xema sabini; common eider Somateria mollissima; long-tailed duck Clangula hyemalis; Ross' gull Rhodostethia rosea) breeding in the low and high Arctic to disturbance from nearby aircraft, as well as avian flight initiation response to humans approaching on foot. All species except nesting long-tailed ducks and common eiders departed their nest when overhead aircraft were within $200 \mathrm{~m}$, with loafing birds often flying off when aircraft were still $1 \mathrm{~km}$ away. There was considerable individual and species-specific variation in responses to approaching humans, with some nesting birds not flushing from their nest until touched by a researcher (e.g., waterfowl; $0 \mathrm{~m}$ ), while others flushed when people were $400 \mathrm{~m}$ away (Ross's gull). Excluding Ross's gulls, 95\% of the individuals of most species did not initiate flight until humans were $\leq 100 \mathrm{~m}$ from the nest, suggesting that this might represent a minimum, suitable "buffer zone" around nesting colonies for non-motorized human activities.

Key words: marine bird, nest, disturbance, Arctic, flush. 


\section{Introduction}

The Arctic supports vast, largely undeveloped terrestrial and marine habitats which support a diversity of iconic wildlife, much of which remains a key source of food for indigenous peoples of the region (Kinloch et al. 1992; Ford 2009). International economic demand and changing environmental conditions are making transport and industrial activities more feasible (Arctic Council 2009). In response, the Arctic is expected to see increases in human activities that will alter habitats, largely extractive resource development, as well marine shipping in the near future (Arctic Council 2009). Much research has been undertaken to identify key habitats of the Arctic region as a means of ensuring that these sites are either protected, or for special management as part of environmental reviews of projects. Aside from identifying the most important habitats for consideration, some research has also considered a variety of less direct effects, such as introduction of novel, invasive species (e.g., Chan et al. 2015), changes to activity patterns and reactions of predators and scavengers to development sites (Johnson et al. 2005; Leibezeit et al. 2009), effects of noise on wildlife (e.g., Richardson et al. 1985; Cosens and Dueck 1993), and the effects of disturbance in areas near wildlife (e.g., Duschesne et al. 2000; Blumstein et al. 2003; Beale and Monaghan 2004). However, most researchers and policy-makers would admit that much remains unknown (e.g., Arctic Council 2009).

For migratory birds, the Arctic offers abundant food resources with which to rear young, and breeding habitats support relatively few predators (McKinnon et al. 2010), but the window of opportunity for breeding is very short (e.g., Mallory and Forbes 2007). Arctic marine birds rely on average or early sea ice breakup for successful reproduction: years with late ice breakup often lead to poor or skipped breeding (Gaston et al. 2005; Levermann and Tottrup 2007). Additional stressors such as years of high predation may also lead to skipped breeding (e.g. 
Levermann and Tottrup 2007; Smith et al. 2010). There are increasing concerns about the synergistic, sublethal effects of anthropogenic chemicals like persistent organic pollutants (e.g., Tartu et al. 2014) as well as the influence of climate change, parasites and diseases (Descamps et al. 2012; Gaston and Elliott 2013) and their role in influencing reproduction. Consequently, breeding Arctic marine birds face a variety of natural and anthropogenic stressors which vary annually, but now will also experience increased intensity or frequency of stressors associated with industrial activity and shipping (Arctic Council 2009).

While much marine bird research in Arctic Canada has focused on factors influencing the health of populations of cliff-nesting species (e.g., Gaston et al. 2005; Mallory and Braune 2012), considerably less is known about those species that nest on flat ground (Gaston et al. 2012; with the exception of some sea ducks, e.g., Kay and Gilchrist 1998; Descamps et al. 2012). Ground-nesting marine birds may be particularly susceptible to a variety of anthropogenic activities that can deleteriously influence their breeding and feeding, such as waves from ships (e.g., PIANC 2003), overflights of aircraft (Pepper et al. 2003), and people approaching by motorized vehicle or on foot near roosting, feeding or nesting sites (Rodgers and Schwikert 2002). Any of these threats can cause birds to flush from nests, exposing their eggs to predators, can cause elevated stress levels in individuals, or simply reduce time necessary for incubation, resting or foraging (e.g. Vleck et al. 2000; Pepper et al. 2003; Wheeler et al. 2009).

I studied the reactions of five species of ground-nesting, colonial marine birds to human disturbance at colonies in the Canadian high Arctic, and two of these species in the low Arctic. My overall goal was to determine an appropriate, minimum setback distance which would not induce significant reactions by nesting birds around the breeding colonies, as a first step in recommending buffer zones in which human activity should be limited around known breeding 
sites. Previous work has shown that many bird species exhibit species-specific flight initiation distances (FID; Blumstein et al. 2003, 2005), meaning that efforts to develop buffer zones around multi-species breeding sites need to consider the reactions of each species to disturbance. Based on earlier work which showed that nest defense ("risk-taking") increases as the breeding season progresses (Forbes et al. 1994; Mallory et al. 1998), I made two predictions for FID among the sympatrically-nesting marine bird species. First, I predicted that sea ducks nesting at the site would have lower FID than the seabirds, because female sea ducks undertake all incubation duties and rely on crypsis to avoid detection during incubation, whereas biparentallyincubating seabirds rely more on deterrence. Second, for terns, active mobbing is their mode of defense (Mallory et al. 2010), and thus I predicted that FID would increase with increasing ordinal date (i.e., birds would depart the nest earlier to protect the clutch as people approached), since terns would have invested more in their nesting attempt as ordinal date increases, and clutches would therefore be of higher reproductive value (Montgomerie and Weatherhead 1988).

\section{Materials and methods}

I collected data on the reactions of ground-nesting marine birds to anthropogenic disturbance at two field sites in the Canadian Arctic: Nasaruvaalik Island in Penny Strait, Nunavut ( $75^{\circ} 49^{\prime} \mathrm{N}$, $96^{\circ} 18^{\prime} \mathrm{W}$ ) in the summers of 2002-2012, and East Bay, Southampton Island, Nunavut (64 $01^{\prime} \mathrm{N}, 81^{\circ} 47^{\prime} \mathrm{W}$ ) in 2010 . Nasaruvaalik Island is a crescent-shaped island, approximately $3 \mathrm{~km} \times$ $1 \mathrm{~km}$ (Mallory and Gilchrist 2003), composed of alluvial gravel that has risen from the surrounding sea due to isostatic rebound from historic glaciation. Arctic terns (Sterna paradisaea, Pontoppidan 1763), Sabine's gulls (Xema sabini, Leach 1819), Ross' gulls (Rhodostethia rosea, MacGillivray 1842), common eiders (Somateria mollissima borealis, 
Brehm 1824), long-tailed ducks (Clangula hyemalis, Leach 1819), and parasitic jaegers (Stercorarius parasitica, Linnaeus 1758) all nest on the island (Maftei et al. 2015), principally among old beach ridges on the low, southwestern and northeastern ends of the island, typically at elevations $<5 \mathrm{~m}$ above sea level (asl). The study site at East Bay was an approximate $2 \mathrm{~km} \times 2.5$ $\mathrm{km}$ block of coastal wetland tundra with numerous brackish and freshwater ponds (Stenhouse et al. 2001). Habitats become increasingly dry moving inland from the coast, including numerous old gravel beach ridges, also the result of isostatic rebound. At this site, terns and Sabine's gulls nest principally near the ponds (Abraham and Ankney 1984; Stenhouse et al. 2001).

In all years, I landed at Nasaruvaalik Island either on a Bell 206B helicopter, or a DeHavilland Twin Otter, and I recorded anecdotal observations of the birds to our approach and landing. I estimated distances by noting my geographic position in the aircraft relevant to nearby features on a map sketched in my field notebook, or recording a GPS waypoint, then observing reactions of birds, and afterwards estimating my distance from the island at the point of FID using Google Earth ${ }^{\circledR}$. During 2002-2006, I recorded the reactions of birds after single day trips landing with a helicopter on the central plateau of the island $(30 \mathrm{~m}$ asl and approximately $1 \mathrm{~km}$ north of the main southwestern tern colony [hereafter "colony"], out of sight of nesting terns and gulls) and after $\sim 10$ min walking into the colony to count nests. In these years, all records were first visits to nests.

In 2007 I established a research camp on the central plateau of the island, and thereafter research was conducted through the nesting season, although we avoided recording duplicate records on nests visited previously that season, as the position of each nest was recorded using a GPS. Study nests were chosen to minimize bias and prior flushing by humans. In 2002-2006 (one day visits), I chose nests where I observed a bird on its nest in the distance, and I 
approached until it flushed, afterwards measuring the distance to the nest. Other nests chosen in those years were distributed at other sites in the colony such that the birds were not already flushed by my earlier movements. In 2007-2012, teams either recorded FID when we first censused nesting birds in a section of the island, or when we had not visited part of the colonies for long periods (generally $>10 \mathrm{~d}$ ). During data collection, researchers walked from the camp to the colony several times daily (except in periods of rain or heavy fog), and focused on a specific nest along the route to the end of the island. They approached off of the central plateau of the island and along a beach ridge toward the colonies, which provided unobstructed views of nests; focal birds could not depart without being seen. They recorded the distance that the bird flushed from its nest (generally estimated to the nearest $5 \mathrm{~m}$ after initially walking off distances earlier in the season and getting an estimate of ranges). In 2010, a field team working on shorebirds on the coastal habitats of East Bay used a similar approach to record FIDs of Arctic terns and Sabine's gulls nesting in their research plots.

Breeding densities of both species are much higher at Nasaruvaalik Island than at East Bay. In most years Nasaruvaalik Island supports $\sim 300$ tern nests in $0.125 \mathrm{~km}^{2}$ in the colony on the south end of the island (i.e., density of 2,400 nests $/ \mathrm{km}^{2}$; Mallory et al. 2010), approximately 57× higher density than in the East Bay area (e.g., 42 nests $/ \mathrm{km}^{2}$; Abraham and Ankney 1984). As well, a minimum of 14 Sabine's gull nests ( $\geq 112$ nests $/ \mathrm{km}^{2}$; Mallory et al. 2012) were established each year at Nasaruvaalik, approximately $3 \times$ higher density than in the East Bay area (30 nests $/ \mathrm{km}^{2}$; Abraham and Ankney 1984), and similarly nests at Nasaruvaalik were typically 2$3 \times$ closer together than in East Bay (Stenhouse et al. 2001; Mallory et al. 2012). One to five Ross's gull nests were established each year at Nasaruvaalik Island (Maftei et al. 2012), always 
situated within the limits of the tern colony. Common eiders nest across the extent of Nasaruvaalik Island.

The distribution of all FID data (ln-transformed) approximated normality $\left(\chi^{2}=10.4, p\right.$ $=0.2$ ), and this held true within each species-site (all $p>0.05$ ), with the exception of Sabine's gull data at East Bay $(p=0.03)$. However, I used one-way ANOVA, followed by Tukey-Kramer Multiple Comparisons tests, to compare among species and sites, and residuals from the test approximated normality, so I report results from parametric analyses (non-parametric KruskalWallis tests gave similar results). I compared FID with ordinal date using linear regression on lntransformed FID data for Arctic terns at Nasaruvaalik Island, but used Spearman correlation for Sabine's gulls due to non-normal distribution of data. Following Burger et al. (2010), I determined the upper $95^{\text {th }}$ confidence limit (CI) from the FID data as a candidate distance to use for establishing the buffer zone around bird colonies. All statistical tests were conducted using Statistica (Dell Software Inc. 2015), with results considered statistically significant if $\alpha<0.05$, and I report means $\pm \mathrm{SD}$ for comparison to studies elsewhere.

\section{Results}

\section{Anecdotal observations}

Each time an aircraft approached Nasaruvaalik Island, I watched the reaction of birds on the ground to our flight. Many terns and most Sabine's gulls and Ross's gulls lifted off their nests when aircraft approached within $\sim 1 \mathrm{~km}$, as did nesting parasitic jaegers, and all of these species appeared to take flight when the aircraft moved over the colony at altitudes $<200 \mathrm{~m}$ on approach to the landing strip. In contrast, most male and non-breeding female common eiders took flight from near nests or loafing ponds when aircraft approached within $500 \mathrm{~m}$, but many breeding 
females remained on their nest. On five occasions I landed on the gravel runway and the wings of the aircraft passed over top of female eiders that remained on their nest. I never observed long-tailed ducks taking flight on aircraft approach. I did not record the precise duration of time between flushing and resettling on the nest, but terns, Sabine's gulls and jaegers appeared to return quickly $(<3 \mathrm{~min})$. Flushed eiders returned much more slowly, often $>30 \mathrm{~min}$. Note that for all of these species, some birds could have departed their nests before coming into my field of view, and thus I could have underestimated FID in some cases, but these observations capture the general pattern observed each time an aircraft approached over several years of arrival flights.

When teams were walking on the island, we observed obvious differences in the responses of each bird species to our presence. Arctic terns and Sabine's gulls exhibited group mobbing behavior when people approached the colony (which was also observed against other predators like glaucous gulls Larus hyperboreus (Gunnerus 1767), jaegers Stercorarius spp., ravens Corvus corax (Linnaeus 1758), Arctic fox Vulpes lagopus (Linnaeus 1758), and polar bear Ursus maritimus (Phipps 1774). With only one breeding pair of parasitic jaegers on the island, people noted that often one member of the pair became airborne and flew over us when we were $>100 \mathrm{~m}$ from the nest, but intense defense by both members occurred when people were within $30 \mathrm{~m}$. Common eiders were highly variable in FID (below), with some individuals flushing while researchers were $>50 \mathrm{~m}$ away, and others allowing people to approach to $1 \mathrm{~m}$ before flushing. Several female long-tailed ducks allowed people to touch them on the nest before they initiated flight.

Flight initiation distance 
The distance at which birds initiated flight off of their nest differed between species and between locations (Table $\left.1 ; F_{6,295}=86.2, p<0.001\right)$. At the East Bay site (Low Arctic), Sabine's gulls and Arctic terns did not differ in their FID from each other $(p>0.05)$. Similarly, at Nasaruvaalik Island (High Arctic) the two species had comparable mean FID ( $p>0.05)$. However, most terns at East Bay flushed when people were $\sim 60 \mathrm{~m}$ farther away than those at Nasaruvaalik Island $(p<0.001)$, mirroring the pattern of Sabine's gulls at the two sites $(p<0.001)$. Ross's gulls flushed when people were $>100 \mathrm{~m}$ farther from the gull's nest than did Arctic terns and Sabine's gulls at Nasaruvaalik Island (both $p<0.001$ ), although there were no significant differences between FIDs of Ross's gulls and terns or Sabine's gulls at East Bay (both $p>0.05$ ). At Nasaruvaalik Island common eiders and long-tailed ducks allowed researchers to approach $>20 \mathrm{~m}$ closer to their nest than terns or gulls at either study site before they initiated flight (all $p \leq 0.01$ ), and long-tailed ducks allowed people to approach and additional $10 \mathrm{~m}$ closer to their nest than eider nests before flushing $(p<0.001)$. Terns and Sabine's gulls at East Bay exhibited more consistency in their flight initiation response: the coefficient of variation on FID was lowest in Sabine's gulls and terns at East Bay, but much more variable in Sabine's gulls, Ross's gulls and Arctic terns at Nasaruvaalik Island. In comparison, variation in eider and long-tailed duck FID was approximately double that of all other species. Only six of 302 FIDs (2\%) were $\geq 200 \mathrm{~m}$, all for Ross's gulls.

At Nasaruvaalik Island in 2008, I focused on ordinal dates and FID to test whether the distance at which birds initiated flight changed through the season. For Arctic terns, birds initiated flight when researchers were farther from their nest as the breeding season progressed (Fig. $1 ; F_{1,76}=4.6, p=0.03$ ), although only a small amount of variation in flushing responses was 
explained by the relationship $\left(r^{2}=0.07\right)$. In contrast, the correlation was negative and nonsignificant for Sabine's gulls $\left(r_{\mathrm{s} 24}=-0.22, p=0.30\right)$.

\section{Buffer zone}

Based on my observations, aircraft caused some marine bird species to flush from their nest when an aircraft was approximately $1 \mathrm{~km}$ from the island, although this was variable. However, for people moving on the land near marine birds, upper 95\% CI of FID ranged from 6-216 m across sites and species (Table 1). If Ross's gulls do not nest in the area of interest, nonmotorized movements by people $>100 \mathrm{~m}$ from the nesting area should result in limited disturbance to most species; this distance needs to be doubled if Ross's gulls are present.

\section{Discussion}

I found considerable variation in the flight initiation distance among species of sympatricallynesting marine birds in the Canadian Arctic. Consistent with my prediction, sea ducks (eiders and long-tailed ducks) remained on their nest only to flush when an observer was quite close, as expected for species where the female relies on her camouflage and remaining motionless to minimize the risk of detection by predators (Goudie et al. 2000; Robertson and Savard 2002). In contrast, Sabine's gulls and Arctic terns are colonial or semi-colonial at these sites (Stenhouse et al. 2001; Mallory et al. 2012), and actively defend their nests against threats, often by interspecific, group mobbing. As such, these species had much larger FIDs than the sea ducks. My results on FID also exhibited some marked similarities to the few previous reports of flushing reactions in the literature for these species. Working at the East Bay field site, Stenhouse et al. (2005) found that Sabine's gulls flushed from their nest at approximately $90 \mathrm{~m}$, close to the $100 \mathrm{~m}$ average I found for birds at this site approximately one decade later. Kay and 
Gilchrist (1998) observed that 90\% of female common eiders flushed when researchers were 4-8 $\mathrm{m}$ from the nest, similar to FID for many other waterfowl species (Forbes et al. 1994), but I found eiders in the high Arctic often initiated flight when people were farther from the nest $(\sim 16$ $\mathrm{m})$. The species which flushed when humans were farthest from the nest (up to $400 \mathrm{~m}$ ) was the Ross's gull. Béchet et al. (2000) suggested that people within 100 m of a Ross's gull cause the birds to flush from the nest, slightly lower than the $166 \mathrm{~m}$ I found. This gull nests up to two weeks earlier than all other species at Nasaruvaalik Island, and is an obvious, bright white "spot" amidst the gray gravel, green moss and orange lichen - presumably an easy target for predators. Thus, the greater FID may be an adaptive behaviour that reduces the risk of nest detection, at least prior to the period when terns and other gulls are nesting around it and engage in group mobbing.

Previous studies have shown that Arctic tern nest defense increases with breeding stage (Lemmetyinen 1971; Whittam and Leonard 2000), and the behaviour of terns in this study was were consistent with these earlier results. Terns at Nasaruvaalik Island initiated flights (to mob the potential predator) when researchers were farther away as the season progressed, indicating more intense defense of the nest. In contrast, both Stenhouse et al. (2005) and I found no difference in the FID of Sabine's gulls as breeding progressed. Stenhouse et al. (2005) attributed this to the relatively consistent, high value of a clutch in the season, because there is no opportunity for renesting, so birds exhibited similar intensity of nest defense throughout incubation. While consistent with parental investment theory (Montgomerie and Weatherhead 1988), it leaves unresolved why Sabine's gulls would exhibit this strategy while co-nesting terns, which similarly have one nesting opportunity at these latitudes and employ group-mobbing behaviour, adjust defense intensity. The FID response clearly varies by species; Burger and 
Gochfeld (1983) found that herring (Larus argentatus, Pontoppidan 1763) and great blackbacked gulls (L. marinus, Linnaeus 1758) waited until an observer was closer to the nest before flushing as the breeding season progressed, opposite of what I observed with terns. These behaviours could represent gulls defending their nest more intensely by reducing exposure of their eggs from a potential predator - nest defense behaviours are often diverse, and which behaviour is used may change through breeding (Montgomerie and Weatherhead 1988). Collectively, these results highlight the arguments of Blumstein et al. $(2003,2005)$ that there is considerable species-specific, and perhaps individual, variation in the FID response of birds to anthropogenic activities.

I found some evidence that nesting density correlated with FID, that is, social facilitation influenced FID (Darling 1938; Erwin 1988), but the result was not in the direction anticipated. If terns exhibit stronger nest defense through breeding by flushing earlier to mob a predator, then I anticipated that terns (and Sabine's gulls) nesting at higher densities (i.e., greater social facilitation) would have larger FID than those nesting at lower densities. However, tern and Sabine's gull nesting densities were much lower at East Bay than Nasaruvaalik Island, and yet FIDs were twice as large at East Bay. I considered two possible explanations for these differences. First, at Nasaruvaalik Island, avian predators are seen regularly but mammals, especially Arctic foxes, occur rarely (Mallory et al. 2012), while at East Bay, both avian predators and foxes are common (Stenhouse et al. 2005; Smith et al. 2010). It is possible that foxes elicit a stronger response than avian predators, leading to East Bay birds having higher FIDs. However, Stenhouse et al. (2005) tested this possibility and found no difference in responses to model mammalian or avian predators near the nest. Second, the intensity of predation pressure at East Bay may be greater than at Nasaruvaalik Island, and nesting birds may 
flush from nests sooner to reduce the risk of nest detection, while also trying to drive predators away. This hypothesis is also not supported by the data: the index of predation pressure at East Bay ( 0.01-0.02 predator sightings per observer hour; Smith et al. 2010) was lower than at Nasaruvaalik Island ( $\sim 0.5$ per hour; calculated from Mallory et al. 2012). Thus, the differences in FID between sites must result from other ecological or behavioural conditions at the site that I did not measure.

From a conservation perspective, the changes that occur in FID through the breeding season per species, or the intercolony differences in FID are much less important than determining the maximum safe distance at which humans can approach nesting birds of each species before eliciting FID reactions, irrespective of stage of breeding. There have been numerous reviews examining this on other waterbird species. For example, Carney and Sydeman (1999) summarized 64 studies on a variety of marine birds and suggested that $3-180 \mathrm{~m}$ were appropriate setback distances to minimize disturbance, depending on the type of birds being approached, but that for Charidriiformes (gulls and terns), minimum recommendations were 100 m. Erwin (1988) recommended greater set-back distances of 100-200 m for terns and skimmers (Rhynchos niger, Linnaeus 1758), similar to the $180 \mathrm{~m}$ recommended by Rodgers and Smith (1995). Chatwin et al. (2013) suggested $50 \mathrm{~m}$ as a suitable setback distance for boat traffic for several species of nesting marine birds, including cormorants, gulls and auks. Hillman et al. (2015) found little evidence for negative effects of aircraft or human traffic on several species of nesting waterbirds, including terns, in a protected area, but noted that the enforced setback distance of $>50 \mathrm{~m}$ during the nesting season probably contributed to this. For non-nesting terns and gulls, Rodgers and Smith (1997) recommended > 100 m and Rodgers and Schwikert (2002) suggested $140 \mathrm{~m}$ as a suitable setback distance to minimize reactions. What is consistent among 
these studies and the results from the Arctic is that across species and colony sizes or locations, relatively few small gulls and terns appear to initiate flight when humans are $\geq 100 \mathrm{~m}$ of nests, and certainly $200 \mathrm{~m}$ is well above most recommended setback distances.

Does flushing these birds influence reproductive success? Carney and Sydeman (1999) reviewed multiple studies which clearly showed that various levels of disturbance can have deleterious impacts on ground-nesting marine bird reproduction, from nest abandonment to skipping breeding. In contrast, Nisbet (2000) critiqued the Carney and Sydeman (1999) paper, and suggested that for terns and gulls, there was little evidence that human disturbance caused substantial harm to colonies. For Nasaruvaalik Island, data do not suggest that researchers flushing birds led to reduced reproductive success, consistent with Nisbet's (2000) review. Sabine's gull nesting success was high in some years and lower in others, presumably influenced by predation, but overall success was good in the high Arctic site where disturbance may have been greater than in the low Arctic site, and gull nesting attempts increased through time (Mallory et al. 2012). Monitoring of reproduction by Arctic terns at Nasaruvaalik Island suggests that terns had annual success typical of Arctic regions, along with high return rates (Mallory unpubl. data). The number of common eiders nesting on the island increased over the years of our study (Maftei et al. 2015). Consequently, for the type of disturbance we created (generally non-motorized approaches by people, as well as 3-5 aircraft flights during the breeding season), there was no obvious, deleterious effect on local populations.

Ground-nesting marine birds in the Canadian Arctic initiated flight from their nests generally when aircraft were within $1 \mathrm{~km}$ of their colony, or when humans approached on foot within $100 \mathrm{~m}$, although there was considerable variation among individuals and species. Furthermore, it is possible that some birds flushed from their nest at greater distances and could 
not be observed from aircraft or possibly during land approaches. I suggest that an approximate doubling of these distances ( $2 \mathrm{~km}$ for aircraft, $200 \mathrm{~m}$ for non-motorized human traffic) would likely ensure that flights or people walking by would create little disturbance to nesting birds. This is an important consideration for some of these uncommon or rare birds, because increasing opportunities for shipping and other industrial activity in the Arctic as climate ameliorates (or as economic opportunity arises) will likely increase the risk of disturbance to Arctic colonies in the future (Arctic Council 2009). Thus, wildlife managers should consider establishing buffer zones around known colony sites (as has been done at many colony sites farther south; e.g., Hillman et al. 2015) to protect these areas. Importantly, additional research is required to examine the effects of motorized vehicles (e.g., outboard motors, all-terrain vehicles) and more frequent flights near these colonies, as increased noise levels may have different effects on these birds. Encouragingly, work at southern sites (e.g., Burger et al. 2010) suggests similar responses to these vehicles as the approach on foot, so setting buffer zones based on available results to date holds promise as an effective initial step in conservation.

Acknowledgements - Financial support for this work was provided by Environment Canada (Canadian Wildlife Service, Interdepartmental Recovery Fund), Natural Resources Canada (Polar Continental Shelf Program), Canadian Wildlife Federation, and Acadia University. I thank the numerous field assistants who worked on terns and gulls at these sites with me since 2007, and Grant Gilchrist for his long-running support of the East Bay field site. All research was conducted under valid annual land use (e.g., N2012N0015) and scientific permits (e.g., WL 2010-042, NUN-SCI-09-01). 


\section{References}

Abraham, D.M., and Ankney, C.D. 1984. Partitioning of foraging habitat by breeding Sabine's gulls and Arctic terns. Wilson Bull. 96: 161-172.

Arctic Council. 2009. Arctic Marine Shipping Assessment 2009 Project Report. Protection of the Arctic Marine Environment Working Group, Akureyri, Iceland.

Beale, C.M., and Monaghan, P. 2004. Human disturbance: people as predation-free predators? J. Appl. Ecol. 41:335-343.

Béchet, A., Martin, J.L., Meister, P. and Rabouam, C. 2000. Second breeding site for Ross's Gull. Arctic 53: 234-236.

Blumstein, D.T., Anthony, L.L., Harcourt, R. and Ross, G. 2003. Testing a key assumption of wildlife buffer zones: Is flight initiation distance a species-specific trait? Biol. Conserv. 110: $97-100$.

Blumstein, D.T., Fernandez-Juricic, E., Zollner, P.A., and Garity, S. C. 2005. Interspecific variation in avian responses to human disturbance. J. Appl. Ecol. 42: 943-953.

Burger, J., and Gochfeld, M. 1983. Behavioural responses to human intruders of herring gulls (Larus argentatus) and great black-backed gulls (L. marinus) with varying exposure to human disturbance. Behav. Process. 8: 327-344.

Burger, J., Gochfeld, M., Jenkins, C.D., and Lesser, F. 2010. Effect of approaching boats on nesting black skimmers: Using response distances to establish protective buffer zones. J. Wildl. Manage. 74: 102-108.

Carney, K.M., and Sydeman, W. J. 1999. A review of human disturbance effects on nesting colonial waterbirds. Waterbirds 22: 68-79. 
Chan, F.T., MacIsaac, H.J., and Bailey, S.A. 2015. Relative importance of vessel hull fouling and ballast water as transport vectors of nonindigenous species to the Canadian Arctic. Can. J. Fish. Aquat. Sci. 72: 1230-1242.

Chatwin, T.A., Joy, R., and Burger, A.E. 2013. Set-back distances to protect nesting and roosting seabirds off Vancouver Island from boat disturbance. Waterbirds 36: 43-52.

Cosens, S.E., and Dueck, L.P. 1993. Icebreaker noise in Lancaster Sound, N.W.T., Canada: implications for marine mammal behavior. Mar. Mammal Sci. 9: 285-300.

Darling, F. 1938. Bird flocks and the breeding cycle. Cambridge University Press, Cambridge.

Dell Software. 2015. Statistica Version 13. Alisa Viejo, California, USA.

Descamps, S., Jenouvrier, S., Gilchrist, H.G., and Forbes, M.R. 2012. Avian cholera, a threat to the viability of an arctic seabird colony? PLoS ONE 7: e29659. Doi:10.1371/journal.pone.0029659.

Duchesne, M., Côté, S. D. and Barrette, C. 2000. Responses of woodland caribou to winter ecotourism in the Charlevoix Biosphere Reserve, Canada. Biol. Conserv. 96: 311-317.

Erwin, R.M. 1988. Correlates of nest-defense behavior of common terns. J. Field Ornithol. 59: $135-142$.

Forbes, M.R.L., Clark, R.G., Weatherhead, P.J., and Armstrong, T. 1994. Risk-taking by female ducks: intra- and interspecific tests of nest defense theory. Behav. Ecol. Sociobiol. 34: 79-85.

Ford, J.D., 2009. Vulnerability of Inuit food systems to food insecurity as a consequence of climate change: a case study from Igloolik, Nunavut. Reg. Environ. Change 9: 83-100. 
Gaston, A.J., and Elliott, K.H. 2013. Effects of climate-induced changes in parasitism, predation and predator-predator interactions on reproduction and survival of an arctic marine birds. Arctic 66: 43-51.

Gaston, A.J., Gilchrist, H.G., and Mallory, M.L. 2005. Variation in ice conditions has strong effects on the breeding of marine birds at Prince Leopold Island, Nunavut. Ecography 28: $331-344$.

Gaston, A.J., Mallory, M.L. and Gilchrist, H.G. 2012. Populations and trends of Canadian Arctic seabirds. Polar Biol. 35: 1221-1232.

Goudie, R.I., Robertson, G.J., and Reed, A. 2000. Common eider (Somateria mollissima). in A. Poole and F. Gill, editors. The Birds of North America, No. 546. The Academy of Natural Sciences, Philadelphia, Pennsylvania, and the American Ornithologists' Union, Washington, D.C., USA.

Hillman, M.D., Karpanty, S.M., Fraser, J.D., and Derose-Wilson, A. 2015. Effects of aircraft and recreation on colonial waterbird nesting behavior. J. Wildl. Manage. 79: 1192-1198.

Johnson, C.J., Boyce, M.S., Case, R.L., Cluff, H.D., Gau, R.J., Gunn, A., and Mulders, R. 2005. Cumulative effects of human developments on Arctic wildlife. Wildl. Monogr. 160: 1-36.

Kay, M.F. and Gilchrist, H.G. 1998. Distraction displays made by female common eiders, Somateria mollissima borealis, in response to human disturbance. Can. Field-Nat. 112: 529-532.

Kinloch, D., Kuhnlein, H., and Muir, D. 1992. Inuit foods and diet: a preliminary assessment of benefits and risks. Sci. Total Environ. 122: 247-278.

Lemmetyinen, R. 1971. Nest defense behavior of common and Arctic terns and its effects on the success achieved by predators. Ornis Fenn. 48: 13-24. 
Levermann, N., and Tottrup, A.P. 2007. Predator effect and behavioural patterns in Arctic terns (Sterna paradisaea) and Sabine's gulls (Xema sabini) during a failed breeding year. Waterbirds 30: 417-420.

Liebezeit, J.R., Kendall, S.J., Brown, S., Johnson, C.B., Martin, P., McDonald, T.L., Payer, D.C., Rea, C.L., Streever, B., Wildman, A.M. and Zack, S. 2009. Influence of human development and predators on nest survival of tundra birds, Arctic Coastal Plain, Alaska. Ecol. Applic. 19: 1628-1644.

Maftei, M., Davis, S.E., Jones, I.L., and Mallory, M.L. 2012. Breeding habitats and new breeding locations for Ross's gull (Rhodostethia rosea) in the Canadian High Arctic. Arctic 65: 283-288.

Maftei, M., Davis, S.E. and Mallory, M.L. 2015. Assessing regional populations of groundnesting marine birds in the Canadian high Arctic. Polar Res. 34: 25055.

Mallory, M.L., and Gilchrist, H.G. 2003. Marine birds breeding in Penny Strait and Queens Channel, Nunavut, Canada. Polar Research 22: 399-403.

Mallory, M.L., and Forbes, M.R. 2007. Does sea ice constrain the breeding schedules of high Arctic northern fulmars? Condor 109: 894-906.

Mallory, M.L., and Braune, B.M. 2012. Tracking contaminants in seabirds of Arctic Canada: temporal and spatial insights. Mar. Pollut. Bull. 64: 1475-1484.

Mallory, M.L., McNicol, D.K., Walton, R.A., and Wayland, M. 1998. Risk-taking by incubating common goldeneyes and hooded mergansers. Condor 100: 694-701.

Mallory, M.L., Boadway, K.A., Boadway, J.J.T., and Akearok, J.A. 2010. Breeding arctic terns kill lemmings. Arctic 63: 359-361. 
Mallory, M.L., Boadway, K.A., Davis, S.E., and Maftei, M.T. 2012. Breeding biology of Sabine's Gull (Xema sabini) in the Canadian High Arctic. Polar Biol. 35: 335-344.

McKinnon, L., Smith, P.A., Martin, J.L., Doyle, F.I., Abraham, K.F., Gilchrist, H.G., Morrison, R.I.G., and Bety, J. 2010. Lower predation risk for migratory birds at high latitudes. Science 327: 326-327.

Montgomerie, R.D., and Weatherhead, P.J. 1988. Risks and rewards of nest defence by parent birds. Quart. Rev. Biol. 63:167-187.

Nisbet, I.C.T. 2000. Disturbance, habituation, and management of waterbird colonies. Waterbirds 23:312-332.

Pepper, C.B., Nascarella, M.A. and Kendall, R.J. 2003. A review of the effects of aircraft noise on wildlife and humans, current control mechanisms, and the need for further study. Environ. Manage. 32: 418-432.

PIANC. 2003. Guidelines for managing wake wash from high speed vessels. International Navigation Association, Report of Working Group 41 of the Maritime Navigation Commission, PIANC General Secretariat, Brussels, Belgium.

Richardson, W.J., Fraker, M.A., Wursig, B. and Wells, R.S. 1985. Behaviour of bowhead whales Balaena mysticetus summering in the Beaufort Sea: reactions to industrial activities. Biol. Conserv. 32: 195-230.

Robertson, G.J., and Savard, J.-P.L. 2002. Long-tailed duck (Clangula hyemalis). in A. Poole and F. Gill, editors. The Birds of North America, No. 651. The Academy of Natural Sciences, Philadelphia, Pennsylvania and the American Ornithologists' Union, Washington, D.C., USA. 
Rodgers Jr., J.A., and Smith, H.T. 1995. Set-back distances to protect nesting bird colonies from human disturbance in Florida. Conserv. Biol. 9: 89-99.

Rodgers Jr., J.A., and Smith, H.T. 1997. Buffer-zone distances to protect foraging and loafing waterbirds from human disturbance in Florida. Wildl. Soc. Bull. 25: 139-145.

Rodgers Jr., J.A., and Schwikert, S.T. 2002. Buffer-zone distances to protect foraging and loafing waterbirds from disturbance by personal watercraft and outboard-powered boats. Conserv. Biol. 16: 216-224.

Smith, P.A., Gilchrist, H.G., Forbes, M.R., Martin, J.-L., and Allard, K. 2010. Inter-annual variation in the breeding chronology of arctic shorebirds: effects of weather, snow melt and predators. J. Avian Biol. 41: 292-304.

Stenhouse, I.J., Gilchrist, H.G., and Montevecchi, W.A. 2001. Reproductive biology of Sabine's gull in the Canadian Arctic. Condor 103: 98-107.

Stenhouse, I.J., Gilchrist, H.G. and Montevecchi, W.A. 2005. An experimental study examining the anti-predator behaviour of Sabine's gulls (Xema sabini) during breeding. J. Ethol. 23: 103-108.

Tartu, S., Angelier, F., Herzke, D., Moe, B., Bech, C., Gabrielsen, G.W., Bustnes, J.O., and Chastel, O. 2014. The stress of being contaminated? Adrenocortical function and reproduction in relation to persistent organic pollutants in female black-legged kittiwakes. Sci. Total Environ. 476-477: 553-560.

Vleck, C.M., Vertalino, N., Vleck, D., and Bucher, T.L. 2000. Stress, corticosterone, and heterophil to lymphocyte ratios in free-living Adelie penguins. Condor 102: 392-400. 
Wheeler, M., De Villiers, M.S. and Majiedt, P.A. 2009. The effect of frequency and nature of pedestrian approaches on the behaviour of wandering albatrosses at sub-Antarctic Marion Island. Polar Biol. 32: 197-205.

Whittam, R.M., and Leonard, M.L. 2000. Characteristics of predators and offspring influence nest defense by Arctic and common terns. Condor 102: 301-306. 
Figure Headings

Figure 1. Map of study sites showing Nasaruvaalik Island in the Canadian High Arctic and East Bay in the Canadian Low Arctic.

Figure 2. Flight initiation distance of Arctic terns in relation to day of the breeding season (as day of year) in 2008 at Nasaruvaalik Island, Nunavut. The relationship is described by the regression equation: Flight initiation distance $=2.567$ (day of year) -439.522 . 
Table 1. Mean (SD) flight initiation distances of incubating, ground-nesting marine birds from two nesting areas in the low and high Arctic, Nunavut, Canada. Values for all species except Ross's gull and long-tailed duck are based on contributions from separate individuals based on first encounter distances. $\mathrm{CoV}$ is coefficient of variation. There were significant differences overall in flight initiation distances among sites and species (ANOVA; $F_{6,295}=86.2, p<0.001$ ); post-hoc Tukey-Kramer Multiple Comparisons tests are given, where groups with different letters had significantly different flight initiation distances $(p<0.05)$ from groups with different letters.

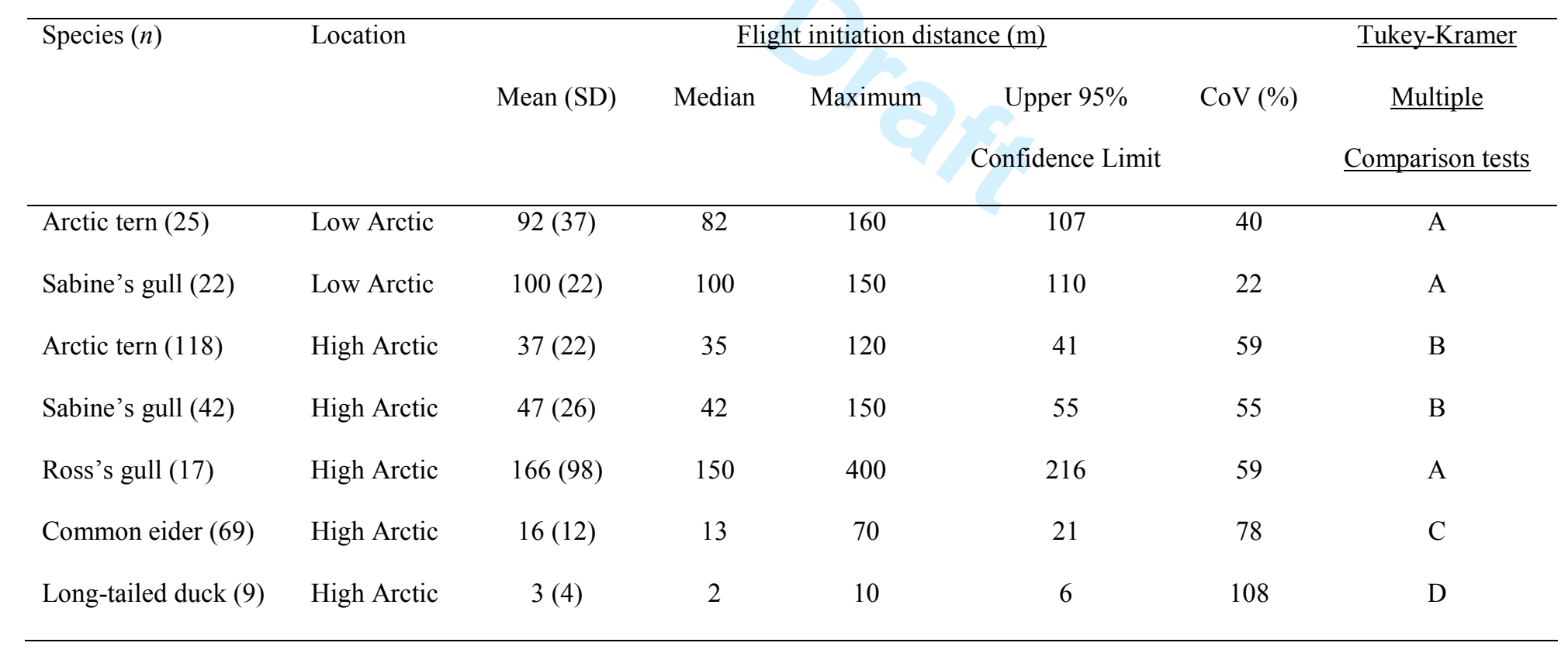




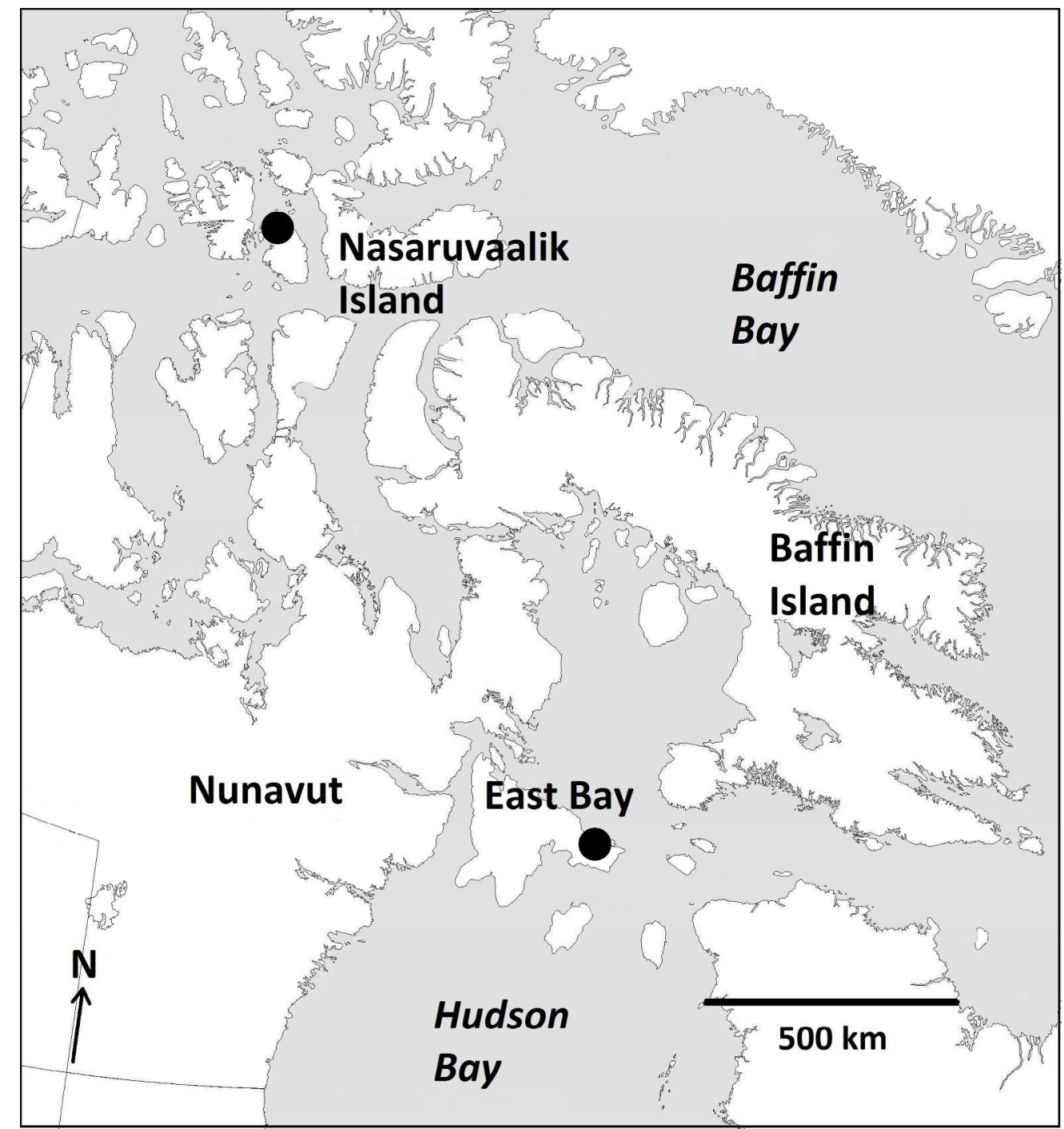

Map of study sites showing Nasaruvaalik Island in the Canadian High Arctic and East Bay in the Canadian Low Arctic.

$293 \times 315 \mathrm{~mm}(200 \times 200$ DPI $)$ 


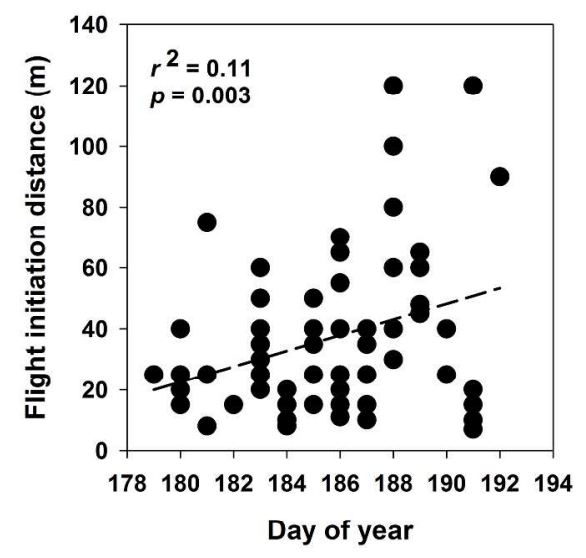

Flight initiation distance of Arctic terns in relation to day of the breeding season (as day of year) in 2008 at Nasaruvaalik Island, Nunavut. The relationship is described by the regression equation: Flight initiation distance $=2.567$ (day of year) -439.522 . $279 \times 361 \mathrm{~mm}(300 \times 300 \mathrm{DPI})$ 